\title{
EFFECTS OF ECONOMIC POLICIES ON STABILITY OF COMPANIES AND EMPLOYEES
}

\author{
Năftănăilă Cristina Alina ${ }^{1}$ \\ Zărnescu Odi Mihaela ${ }^{2}$ \\ Braga Filofteia Viorica ${ }^{3}$ \\ Hurloiu Lacramioara Rodica ${ }^{4}$
}

Received: November 28, 2018 / Revised: January 10, 2019/ Accepted: March 15, 2019

(C) Association of Economists and Managers of the Balkans, 2019

\begin{abstract}
The current study investigates domestic and international economic and financial developments, analyzes the ability of Romanian firms to adapt to the challenges of integration in the euro area and identifies the economic and financial performance of Romanian companies. The economy of the euro area has seen positive developments in the first half of 2017. Economic growth recorded a $0.7 \%$ gain in the second quarter of 2017, after $0.6 \%$ in the first quarter. Also the profitability of euro area banks has improved but the main problem in the euro area is the high level of public and private debt. Romania recorded one of the highest economic growth rates in the EU in the first nine months of 2017. However, the analysis of the main macroeconomic indicators reveals the build-up of tensions.
\end{abstract}

Keywords: economic stability, economic evolutions, financial developments, profitability indicators

JEL Classification E44 $\cdot$ E51 $\cdot$ G28

This paper was presented at the Second International Scientific Conference on IT, Tourism, Economics, Management and Agriculture - ITEMA 2018 - November 8, 2018, Graz, Austria, www.itema-conference.com

Năftănăilă Cristina Alina

naftanailacristina@yahoo.com

Spiru Haret University, Faculty of Economic Sciences, Câmpulung, Romania

Spiru Haret University, Faculty of Economic Sciences, Câmpulung, Romania

Spiru Haret University, Faculty of Economic Sciences, Campulung. Romania

Spiru Haret University, Faculty of Economic Sciences, Bucharest, Romania 


\section{INTRODUCTION}

The level of earnings and the degree of economic stability influence the well-being of a country. The way economic policies influence the stability of macroeconomic aggregates has been highlighted over the years by economists such as Sutherland et al., (2012); Ziemann, (2013); Sutherland and Hoeller, (2013). The main factor of growth was domestic consumption, a major role in stimulating it, among other things, fiscal and income policy measures over the past two years. The scientific research carried out through this article was based on the study, collection and interpretation of the statistical data from the reports issued by the National Trade Register Office, the National Bank of Romania and the Ministry of Public Finance.

\section{INTERNATIONAL ECONOMIC AND FINANCIAL DEVELOPMENTS}

Global macroeconomic conditions have improved compared to the year 2016. The International Monetary Fund has increased projections on the world economy growth rates from 3.6\% for 2017 to $3.7 \%$ for 2018 (Figure 1).

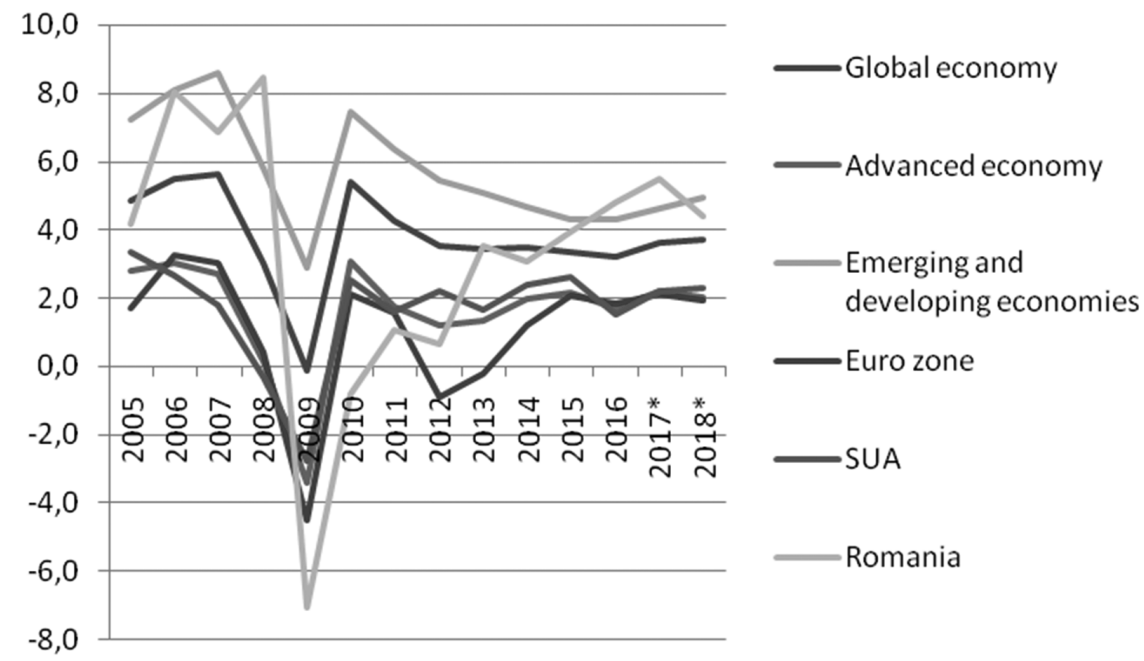

Figure 1. Global economic growth.

Source: Global Financial Stability Report, October 2017, International Monetary Fund

The forecasts for the euro area, Japan, as well as the emerging economies in Asia and Europe have been revised on the rise, while those for the US and the UK have been declining reviews. In reconfiguring the projections, an important factor was the revitalization of trade at global level. The World Trade Organization estimated for the year 2017 an increase in the volume of trade of goods with values between 1.8 and 3.6\%, from 1.3\%, estimated value for the year 2016 .

However, the risks of enhancing the growth rate of the global economy and international trade remain important amid the uncertainty of policies (both commercial and monetary), the accumulation of structural imbalances in The level of emerging economies (particularly in China and Brazil) and the increase in geopolitical tensions, as well as the placement of fuel prices at lower levels over the last few years. 
In the first part of the year 2017, the international financial markets recorded positive developments after the corrections recorded at the end of 2016, while volatility was on a reduction trend, with short periods of amplification. The positive developments supported by the stock indices of the main capital markets, as well as the beginning of the normalization process on the European sovereign bonds markets (Figure 2) were determined by the improvement of the indicators Macroeconomic reforms, the continuation of the quantitative relaxation programme by the ECB, as well as the optimistic expectations of investors on the perspectives of the world economy. A concern at financial stability is the risk of improper valuation of financial assets, given the continuation of the high-yield search phenomenon, under the conditions of maintaining the low interest level.

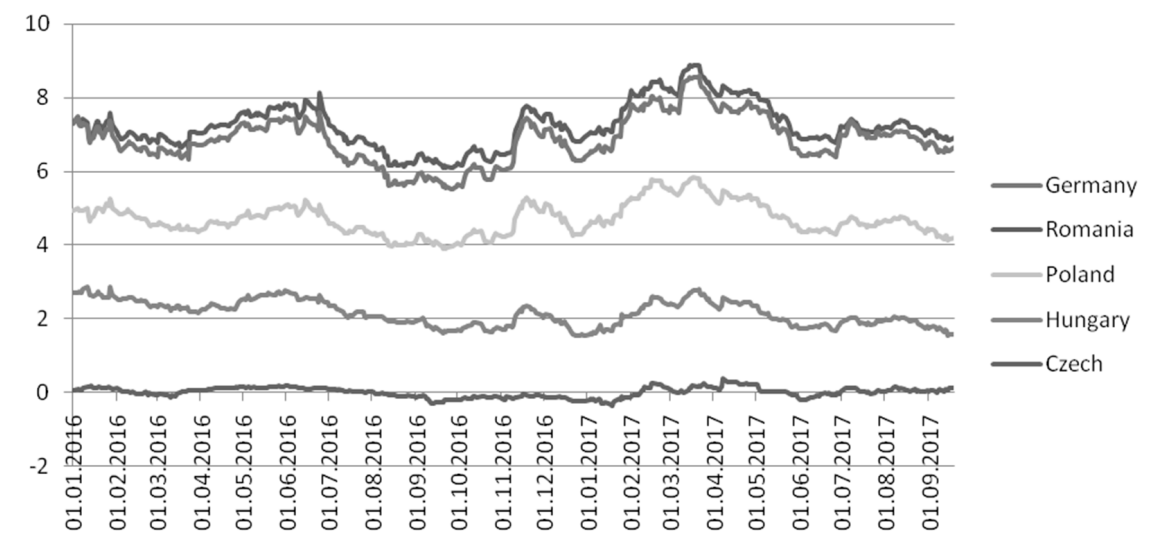

Figure 2. Yield of 5-year sovereign bonds for some European Union countries. Source: Raport asupra stabilitatii financiare 2/2017, www.bnr.ro

As assessed by the International Monetary Fund of October 2017 (Global Financial Stability Report), the main systemic risks to the financial system at global level are:

- Market and liquidity risk, determined by the low level of interest rates and risk premiums, as well as the low level of volatility in international financial markets;

- Risks from emerging markets;

- Credit risk, in particular as a result of developments in the risk associated with population lending and-macroeconomic risk. The risk for emerging markets and the macroeconomic risk are evaluated in the fall against the estimated values in April 2017, amid the resumption of global economic growth.

The latest analyses of the European Central Bank and the European Systemic Risk Board at European Union level on the development of risks and vulnerabilities in relation to financial stability show a pronounced increase in risks, coming from:

- -Sudden adjustment of the risk premium on the international financial markets;

- -The balance sheet situation and the low profitability of financial institutions;

- - The uncertainty of the political framework and the challenges regarding the sustainability of the public and private sector debt, as well as-the liquidity and the contagion of the parallel banking sector.

An important systemic risk to financial stability in Romania, similar to that at European Union level, is the steep adjustment of the risk premium for emerging economies. The implementation of a mix of policies leading to the maintenance of macroeconomic balances is an important condi- 
tion in order to limit the effects of contagion from international financial markets, under the conditions that materialize the risk of sudden change in investor confidence in emerging economies.

The economic situation in the euro area has improved, but important vulnerabilities on medium-term prospects persist.

In the first part of the year 2017, the euro area economy recorded positive developments. Economic growth recorded an advance of $0.7 \%$ in the second quarter of the year 2017, after the value of $0.6 \%$ of the first quarter.

The profitability of euro area banks has improved, but the prospects remain mixed.

The profitability of banks in Europe recorded a slight improvement in the first half of the year 2017. Thus, the average profitability of capital (ROE, return on equity) increased in the second quarter of the year 2017 with 3.7 percentage points compared to the last quarter of 2016, reaching $7 \%$. Also, the average profitability of assets (ROA, return on assets) increased to $0.45 \%$ in the same period, from $0.21 \%$ to the end of 2016 .

The prospects for the profitability of the European banking sector remain mixed. On the one hand, the still high volume of non-performing loans in some European states (figure 3) and a number of structural factors, such as the level of competition in certain segments of the credit market, contributes to maintaining operational revenue Low. On the other hand, the revival of the lending activity will support the process of normalization of profits. Loans to non-financial corporations in the euro area increased by an annual rate of $2.5 \%$ in September 2017, while loans to the population registered an advance of $2.7 \%$ during the same period.
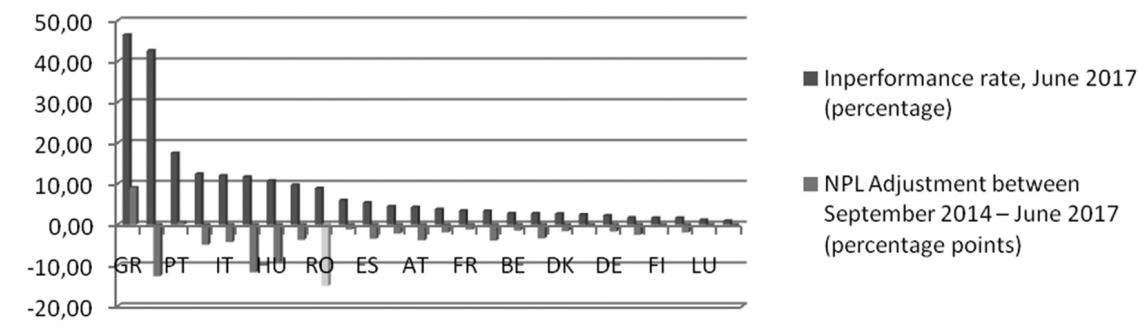

Figure 3. Non-performance rates in EU countries. Source: Raport asupra stabilitatii financiare 2/2017, www.bnr.ro

Romania is among the countries with the highest level of profitability, along with other countries in the region such as the Czech Republic, Bulgaria, and Hungary (Figure 4).

Romanian banks with Italian capital, Greek or Cypriot, respectively, are characterized by a high degree of capitalization (have the total own funds rate of $15.2 \%$ for Italian capital banks, respectively 23\% for those with Greek and Cypriot capital, September 2017) and an adequate level of coverage with provisions (48\% for Greek and Cypriot capital institutions, respectively $69.4 \%$ for those with Italian capital). 


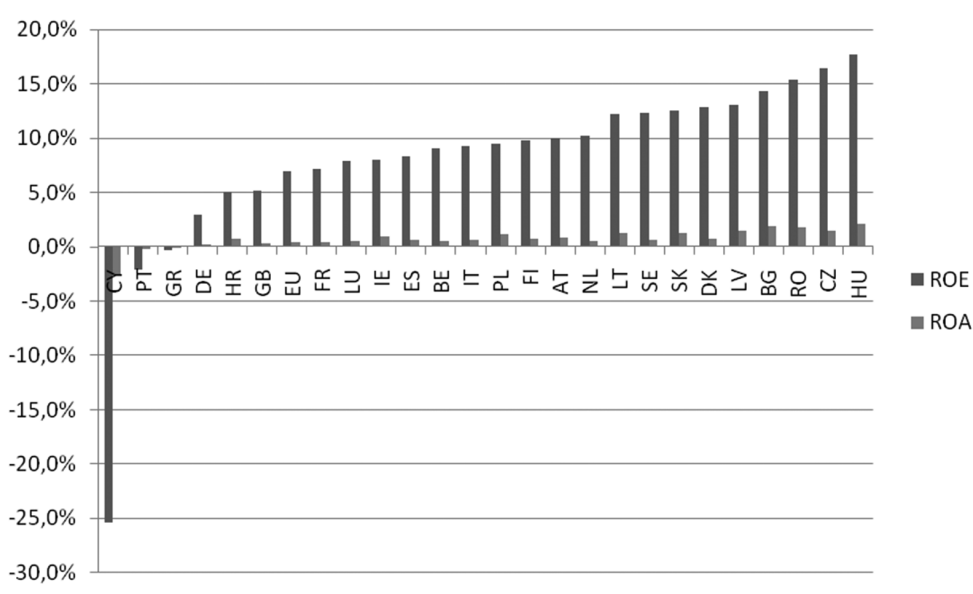

Figure 4. Profitability of banks in the European Union (June 2017).

Source: Raport asupra stabilitatii financiare 2/2017, www.bnr.ro

The main problem in the euro area is the high level of public and private debt.

The sustainability of the public debt continues to be an important issue in some States of the European Union. The high level of debt in these states (Figure 5), in the context of increasing inflationary pressures, will have the effect of increasing funding costs.

Developments continue to be heterogeneous at the level of countries although at the aggregate level there has been a slight improvement in fiscal position. This trend is expected to continue in the coming period as well. Thus, the level of public debt was estimated to adjust slightly from 85.1\% of GDP in 2016 to 84.8\% of GDP in December 2017 (EU average), respectively from 91.3\% of GDP to $90.3 \%$ of GDP (euro area).

The budget deficit in the European Union decreased to $1.7 \%$ in 2016, with a deficit of $1.6 \%$ of GDP in the year 2017. In November 2017, two euro area states (France and Spain) are under the excessive deficit procedure, decreasing from nine states, of which seven in the euro area in the first part of the year 2016.

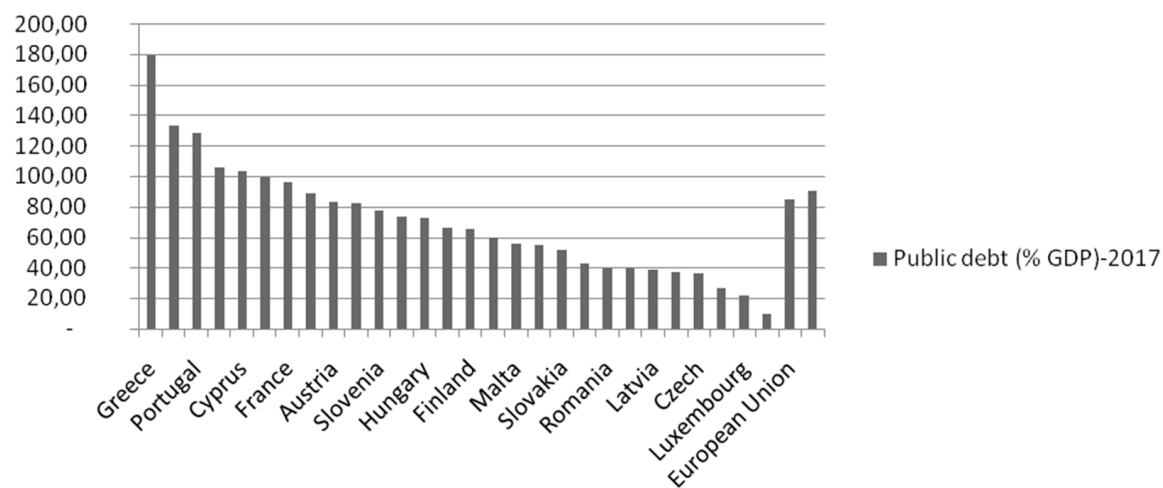

Figure 5. Public debt in the European Union, Source: Eurostat 
The risks to the European financial system from the investment funds sector, insurance companies and pension funds require careful monitoring

The development of the investment funds sector can represent a risk zone for European financial stability, the resumption of its growth representing a concern at European level. Unlike this, the risks from the insurance sector are maintained at a low level, but the environment characterized by low yields is still an important concern for the EU insurance industry.

As regards the pension fund sector, the risk of a revaluation of the prices of fixed-income financial instruments, in the context of the start of the process of normalization of monetary policy at European level, may result in significant losses in Level of this sector.

\section{INTERNAL MACROECONOMIC DEVELOPMENTS}

Romania recorded one of the highest rates of economic growth in the European Union in the first nine months of the year 2017. The analysis of the main macroeconomic indicators reveals the accumulation of tensions, with possible significant negative consequences for future economic developments and, implicitly, on financial stability. The main growth factor was the internal consumption, a major role in stimulating it with, inter alia, fiscal policy and income policy measures over the past two years.

In the first semester of 2017, economic activity recorded an advance of 5.8\%, with domestic consumption contributing 5.5 percentage points, while net exports had a negative contribution. Investments have had a marginal contribution to economic growth, as seen in the following chart:

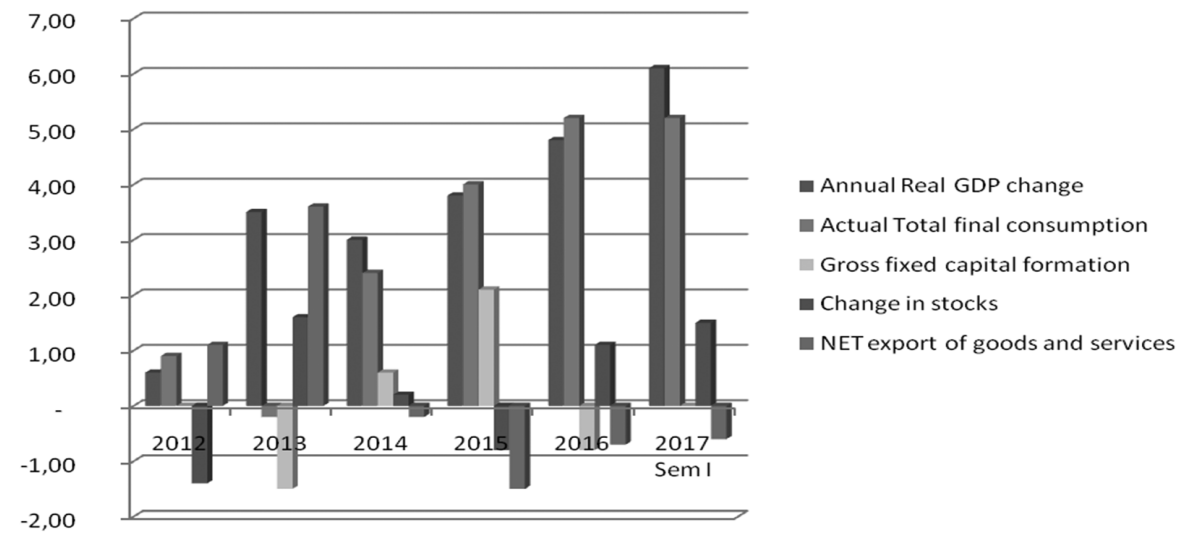

Figure 6. Explanatory factors of GDP dynamics. Source: National Institute of Statistics http://statistici.insse.ro/

The acceleration of domestic demand had the effect of increasing imports, while the low level of investment limited the capacity of domestic production to refill excess domestic demand. The continuation of these developments and in the coming period will most likely lead to an increase in tensions on the main macroeconomic balances.

The continuation of the convergence process is conditional on recalibrating the policy mix so as to ensure that fundamental economic indicators are maintained at viable levels. 
In order to achieve an optimum mix of policies for the Romanian economy, cooperation between institutions with role in the coordination of economic policies is essential. BNR cannot refill the lack of adequate policies in areas other than those in its area of competence, a different approach leading, among other things, to the inefficiencies of monetary policy. It is also necessary to intensify efforts to create a framework conducive to stimulating investment in the private environment and improving public investment in order to ensure sustainable economic growth.

Some of the possible measures in this regard are: increasing the level of coherence of policies and predictability of the legislative framework, reducing inequalities, and giving greater attention to basic public services with a major role in Enhancing long-term economic growth (education and health services).

At regional level continuing inequalities in the degree of economic development continue to persist, and in the absence of consistent structural reforms it is possible to witness even an increase. Firstly, the difference between the levels of development of the regions in Romania is large relative to the dispersion of regions in other Member States (Figure 7).

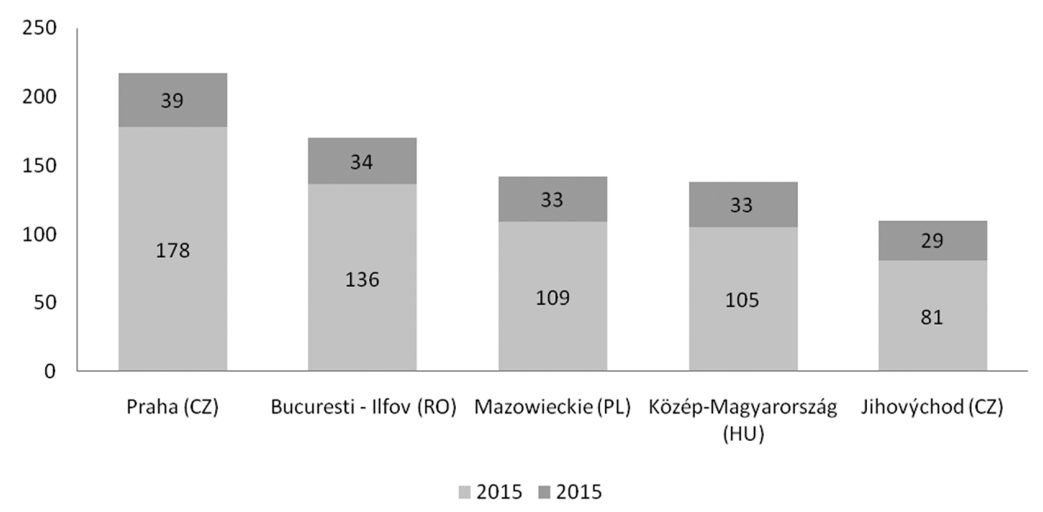

Figure 7. GDP/capita PPS at regional level in Central and Eastern European countries (2015). Source: Eurostat

The region of Bucharest-Ilfov is among the top five regions in the area of central East European countries within GDP/capita, while the northeast region is among the poorest in the EU.

The growth rate is lower in regions with low levels of development, indicating an increase in time disparities. In the period 2007-2017, Bucharest has improved its GDP/capita ratio by 30 percentage points to the European Union average, while the Northeast region has only increased by 7 percentage points.

Investments are concentrated in the Bucharest-Ilfov region, with the other regions registering significantly lower values.

In all regions, with the exception of the Bucharest-Ilfov area, the share of the population with a low level of education (primary and secondary education) is important (on average $24 \%$ of the region's population, compared with 13\% in Bucharest-Ilfov, data for the year 2016).

The level of unemployment varies significantly from one region to another: The highest rate is recorded in the Southwest Oltenia region $(9.9 \%$ in 2016) and the lowest in the Northeast region 
(3\% in the same period). However, the low unemployment rate in the north-east region can also be influenced by the high number of people working in agriculture and the lack of job offer under the conditions of an important emigration of the population in this region.

\section{THE CAPACITY OF ROMANIAN COMPANIES TO ADAPT TO THE CHALLENGES OF INTEGRATION IN THE EURO AREA}

In all economic processes, economic operators who meet certain specific roles in their initiation and maintenance, in their supply or inaccuracy, are involved. Whether economic processes are addressed on a micro scale or macro scale, their determinism is the nature of their own behavior to certain economic operators (Avram, 2017).

A critical mass of companies has been formed in Romania that can cope with the challenges of eventual membership of the euro area. Economist Neagu F. (2017) believes that the number of firms composing critical mass is relatively low (less than $10 \%$ of the total number of active firms in the economy). These companies have recorded economic and financial performance indicators superior to the rest of the economy and constitute the basis for sustainable economic growth.

A number of characteristics specific to the Romanian economy retain the transfer of a large number of non-financial companies in the category of performance firms and the reduction of the competitiveness gap towards euro area companies:

- unfair competition generated by firms with LAX budget constraints;

- excessive bureaucracy;

- low quality and insufficient development of infrastructure;

- the reduced degree of absorption of the non-refundable European funds;

- predominance of companies that are technologically weak or providing services with a ow degree of innovation;

- reduced correlation between educational offer and labour demand;

- unpredictable fiscal framework, etc.

According to the National Bank of Romania's survey on access to financing of non-financial companies in Romania, the unpredictability of the fiscal environment has at least moderate impact for $86 \%$ of companies. Companies with a high degree of adaptation and holding financial and human resources to accommodate tax changes, but also firms with a better negotiating position in relation to suppliers cope better with the rigors of the Romanian business environment. The identification of solutions to the above mentioned aspects can lead to the narrowing of the competitiveness corridor between the Romanian economy and the euro area economies.

\section{ECONOMIC AND FINANCIAL PERFORMANCE OF COMPANIES IN ROMANIA}

During the year 2016, companies in Romania continued their favorable developments in recent years, while improving the nationally-recorded economic situation. Thus, the sector of non-financial companies generated value added in growth by $5 \%$ compared to the year 2015 , in the context of a turnover higher than the previous year $(+4.4 \%)$. At the same time, the positive dynamics of the number of employees $(+1.2 \%)$ and holdings of total assets $(+1.5 \%)$ were maintained.

The favorable economic environment of the last period has also translated into a positive natural growth at the level of the company's population, the ratio between newly created firms and those that have ceased activity being over united. 
At the end of 2016, the aggregate net result reported by non-financial companies was 51.3 billion lei, compared with 36.9 billion lei in the previous year, amid increased sales, in conjunction with the less accelerated dynamics of Operating expenses $(+3.4 \%)$.

It reflects the contribution of two populations of opposite companies as performance: those with net profit by 84.3 billion lei and those that record negative net result of 33 billion lei. In this context, Romanian non-financial companies reported a level of expenditure on the profit tax of 12.7 billion lei. From a sector point of view, the highest contributions are recorded in the trade sectors $(28.3 \%)$, the manufacturing industry $(22.8 \%)$ and services $(22.3 \%)$.

Spread between the numbers of companies for which a negative net result was recorded and that of companies that registered profit continued to increase. However, it is noted, for the second consecutive year, a sustained growth rate of wages expenditure (12.2\%), which shows an increase in pressure on the competitiveness and profitability of Romanian companies. At the same time, companies ' constraints in finding staff suitable for the continuation of activity, as well as the need to increase the share of higher value-added activities in the economy, require an increase in expenditure with employees.

Wage growth is a trend that begins to manifest in many European countries, supported including pressure for a fairer division of the company's results between the capital factor and the labour factor (Georgescu, 2016).

More than half of the non-financial companies registered profit at the end of the year 2016, while onethird of them recorded losses. About $90 \%$ of losses and more than $93 \%$ of profits were made by private companies. Both net profits and losses are characterized by a high degree of concentration, also observed in previous years. The first 100 companies with a positive net result accumulate about $25 \%$ of the profits, while in the case of losses the first 100 companies are responsible for $33 \%$ of the total.

The measure of the upward performance of non-financial companies is given by the advance of key indicators, such as capital profitability (ROE), which increased substantially (from 14.5\% in 2015 to $17.3 \%$ in 2016), and asset profitability (ROA), which reached a level of $5.6 \%$ in 2016 , compared with $4.6 \%$ in the preceding financial year (Figure 8 ). The profitability of Romanian companies is similar to the average level in the European Union.

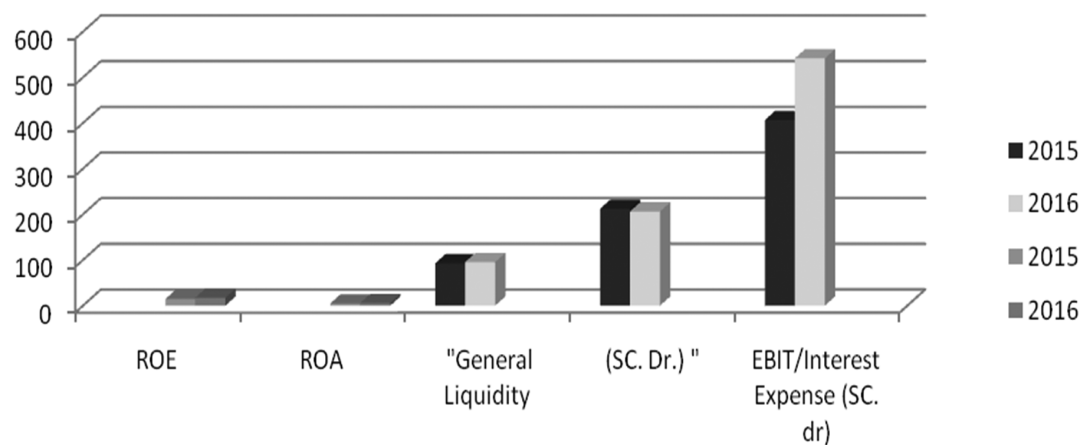

Figure 8. Financial health indicators of the company sector, Source [11]

For every euro made from sales the resulting profit is about 9 eurocents. 
The sector of small and medium-sized enterprises has known performance over those recorded by corporations in terms of profitability, gross added value (Figure 9). However, corporations continue to record higher productivity values. Thus, although small and medium-sized enterprises have an almost double number of employees, contributions to gross value added or turnover of the two categories of companies are relatively close to the value. This situation is determined by factors such as better capacity to recover claims, diversify markets, better investment financing, major differences in technological advance integration, etc.

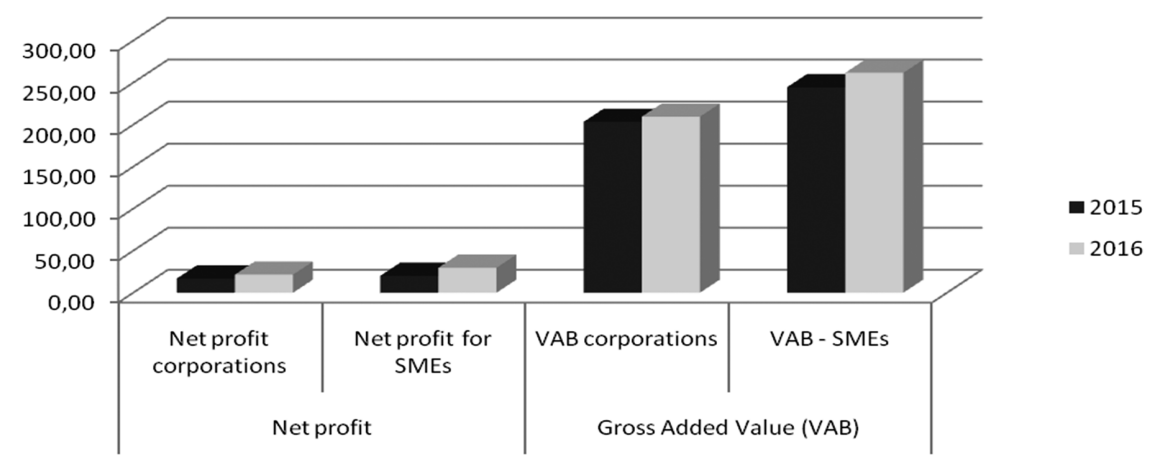

Figure 9. Profitability and contribution to gross value added by company size, Source: Ministry of Public Finances, Annual Report, Activity of public enterprises in the year 2016

By field of activity, most business sectors experienced favorable returns in terms of profitability ratios (i.e. return on capital above 15\%), excluding utilities and extractive industries, in the context of EBIT margins (earnings before interest and tax) or rotation speeds of increasing assets.

\section{CONCLUSION}

The economy of the euro area has seen positive developments in the first half of 2017. Economic growth recorded a $0.7 \%$ gain in the second quarter of 2017 , after $0.6 \%$ in the first quarter. Also the profitability of euro area banks has improved but the main problem in the euro area is the high level of public and private debt.

Romania recorded one of the highest economic growth rates in the EU in the first nine months of 2017, but the analysis of the main macroeconomic indicators reveals the build-up of tensions. The main factor of growth was domestic consumption, a major role in stimulating it, among other things, fiscal and income policy measures over the past two years. A number of characteristics specific to the Romanian economy prevent the transfer of a large number of non-financial companies into the category of performing firms and the reduction of the competitiveness gap with the euro area firms:

- unfair competition generated by companies with lax budget constraints;

- excessive bureaucracy;

- low quality and insufficient infrastructure development;

- the low degree of absorption of European non-reimbursable funds;

- the preponderance of poorly-engineered or low-service companies;

- the low correlation between the educational offer and the demand for labor;

- the unpredictable fiscal framework, etc. 
Businesspeople look with temperamental optimism and even with some signs of concern the real evolution of the economy this year. Inflation, depreciation of the lei and uncertainties related to the fiscal framework are the main signals raised by the business environment.

\section{REFERENCES}

Avram L. G. ”Economie Teorie și aplicații”, Editura Economică, București, 2017, p. 45

Eurostat, https://ec.europa.eu/eurostat/statisticsexplained/index.php?title=National_accounts_and_ GDP

Georgescu, F. - „Creșterea economică, dezvoltarea României și reducerea sărăciei”, prezentare susținută în cadrul conferinței Dezvoltarea României și politicile anti-sărăcie organizată de Şcoala Națională de Studii Politice și Administrative, mai 2016, p.6, https://www.bnr.ro/ Prezentari-si-interviuri--1332.aspx

Global Financial Stability Report, October 2017, INTERNATIONAL MONETARY FUND pdf. p.20 https://www.imf.org/en/Publications/GFSR/Issues/2017/09/27/global-financial-stability-report-october-2017

Ministry of Public Finances, Annual Report, Activity of public enterprises in the year 2016, pdf. p. 77, http://discutii.mfinante.ro/static/10/Mfp/guvernanta/RAPORTANUAL2016PRIVINDACTIVITATEAIP_27112017.pdf

National Institute of Statistics http://statistici.insse.ro/

Neagu, F., Dragu, F., Costeiu, A. - „Pregătiți pentru viitor? O nouă perspectivă asupra economiei României”, caiete de studii, no 46/2017, p.20 https://www.bnr.ro/Caiete-de-studii-484.aspx

Raport asupra stabilitatii financiare 2/2017, www.bnr.ro, p.16-17

Sutherland, D. and P. Hoeller (2013), "Growth-promoting Policies and Macroeconomic Stability”, OECD Economics Department Working Papers, No. 1091, OECD Publishing, https:// dx.doi.org/10.1787/5k3xqsz7c8d2-en

Sutherland, D., P. Hoeller, R. Merola and V. Ziemann, (2012), "Debt and Macroeconomic Stability”, OECD Economics Department Working Papers, No. 1003, OECD Publishing, https:// ideas.repec.org/p/oec/ecoaaa/1003-en.html

Ziemann, V. (2013), “Do Structural Policies Affect Macroeconomic Stability?” OECD Economics Department Working Papers, No. 1075, OECD Publishing, https://dx.doi.org/10.1787/5k$43 \mathrm{krffl} \lg x \mathrm{t}-\mathrm{en}$ 